\title{
Polyene production of antagonistic Streptomyces species isolated from Sphagnum peat
}

\author{
OlAVI RAATIKAINEN, JOUKO TUOMISTO, RISTO TAHVONEN and \\ HEIKKI ROSENQVIST
}

\begin{abstract}
Raatikainen, O., Tuomisto, J., Tahvonen, R. \& Rosenqvist, H. Polyene production of antagonistic Streptomyces species isolated from Sphagnum peat. Agric. Sci. Finl. 2: 551-560. (Dept. of Pharmacology and Toxicology, and Dept. of Pharmaceutical Chemistry, University of Kuopio, FIN-70211 Kuopio, Finland, Division of Environmental Health, National Public Health Institute, FIN-70701 Kuopio, Finland, Inst. of Plant Protection, Agric. Res. Centre of Finland, FIN-31600 Jokioinen, Finland and Dept. of Biochemistry and Microbiology, Helsinki University of Technology, FIN-02150 Espoo Finland.)
\end{abstract}

Several isolates of Streptomyces species, suppressive against fungal growth and obtained from light-coloured Sphagnum peat, produced polyene antibiotics. The mechanism of growth suppression by these isolates is probably partially explained by antibiosis, since there was a significant difference in the antibiotic production by suppressive vs. non-suppressive isolates. The antibiotic consists of several individual components, which form an aromatic heptaene complex of the candicidin type containing p-aminoacetophenone and mycosamine moieties. The minimum inhibitory concentration (MIC) of the antibiotic against yeasts and fungi was the same as that of candicidin.

Keywords: biocontrol, antibiosis, polyenes, Streptomyces

\section{Introduction}

Biological control of phytopathogens by various Streptomyces species has been studied for decades, and many reports have been published about the role of antibiotics in this phenomenon (SNEH and HeNIS 1972, GotTlieb 1976, Rothrock and GoTTLIEB 1981, ROTHROCK and GOTTLIEB 1984, Williams 1986, Fravel 1988, Weller 1988). Data concerning the relationship between antibiotic productivity in vitro and biocontrol both supports and opposes this view. Polyene antibiotics are often produced by the actinomycetes isolated from different soils (MARTIN and MCDANIEL 1977). In vitro production of a polyene antibiotic in connection with the suppression of phytopathogenic fungi has been previously reported but no further characterization of this polyene has been performed (SNEH and HENIS 1972). Hence, the correlation of the antagonistic activity of Streptomyces bacteria and their ability to produce polyene antibiotics in vitro still seems to be unclear.

Finnish Sphagnum peat has been a source for a number of Streptomyces isolates which were demonstrated to be effective suppressors of plant diseases caused by Fusarium spp., Alternaria spp. and other phytopathogenic fungi (TAHVONEN 1982a,b, TAHVONEN and AVIKAINEN 1987, TAHVONEN 
1988). One of these isolates, identified as Streptomyces griseoviridis (LAHDENPERÄ et al. 1991), was introduced as a biological pesticide against fungal plant diseases (LAHDENPERÄ 1991). Preliminary experiments on agar plates indicated that the suppressive isolates could produce some non-volatile factors, and HPLC studies on the chemical nature of the antifungal activity of $S$. griseoviridis revealed the production of a candicidin type heptaene complex (RAATIKAINEN 1991). Thus, antibiosis could be a partial explanation for the mechanisms of action by the suppressive isolates due to the production of this heptaene in the environment of the growing bacteria.

The production, isolation and further characterization of this heptaene polyene are described in this study. The production of heptaene by eight suppressive and four non-suppressive Streptomyces species, cultured on liquid or agar medium, was compared. The antifungal activity of the heptaene was estimated by determining the MIC value against yeast and mold cells.

\section{Material and methods}

\section{Strains}

The suppressive and non-suppressive Streptomyces isolates were selected on the basis of their antagonistic effectiveness against the growth of phytopathogenic fungi in greenhouse experiments determined by previously described methods (TAHVONEN 1982a,b). The seeds were sawn into plastic pots (volume about 11 ) at a density of 36 cauliflower seeds per pot, in quadruplicate replications of each Streptomyces isolate. Steamed peat was used as the growing substrate, and the cauliflower seedlings were grown for 3.5 weeks.

The degree of infection was determined by disease index at the end of the experiment using a scale of $0-2$, where $0=$ healthy, 1 = slightly damaged foot at the stem, and $2=$ severe foot damage or dead seedlings. The efficiency rate against damping-off was also determined (Table 1).

Infection of the seeds was ensured by immersing
Table 1. Antagonistic activity of Streptomyces isolates on Alternaria -damping-off of cauliflower.

\begin{tabular}{lcc}
\hline $\begin{array}{l}\text { Streptomyces- } \\
\text { isolate no }\end{array}$ & $\begin{array}{c}\text { Effect-\% } \\
\text { on damping-off }\end{array}$ & $\begin{array}{c}\text { Disease index } \\
0-2\end{array}$ \\
\hline & & \\
6 & 97 & 0.47 \\
61 & 99 & 0.22 \\
116 & 98 & 0.34 \\
601 & 95 & 0.25 \\
606 & 91 & 0.30 \\
607 & 87 & 0.47 \\
611 & 94 & 0.30 \\
624 & 91 & 0.36 \\
614 & 40 & 1.28 \\
714 & 32 & 1.43 \\
728 & -17 & 1.08 \\
740 & 5 & 1.80
\end{tabular}

Efficiency rate is described as Effect- $\%=(\mathrm{A}-\mathrm{B}) /(\mathrm{C}-\mathrm{B})$ $\times 100$, where

A $=$ Number of healthy plants; seeds infected with $A$. brassicicola and treated with Streptomyces;

B = Number of healthy plants; seeds infected with $A$. brassicicola and not treated with Streptomyces

$\mathrm{C}=$ Number of healthy plants; seeds not infected and not treated with Streptomyces

Isolate 61 is previously identified as $S$. griseoviridis.

cauliflower seeds in an Alternaria brassicicola suspension containing 2-week-old fungal mycelia grown on PDA medium in a Petri dish $(100 \mathrm{ml}$ of seeds/dish was used). The seeds were finally dried between filter papers before use.

The solution of Streptomyces needed for the seed treatment was prepared by homogenizing the mycelia scraped from the surface of the YMG agar in sterile water. The seeds were treated by soaking them for $5 \mathrm{~min}$ in a suspension of Streptomyces containing $10^{8}-10^{9} \mathrm{cfu} / \mathrm{ml}$, and finally dried overnight between filter paper sheets.

Plant pathogenic isolates of Fusarium culmorum (W.G.Sm.) Sacc., Alternaria brassicicola (Schwein.) Wiltsch. and Botrytis cinerea Pers. ex Nocca \& Balbis (Agricultural Research Centre of Finland, Jokioinen, Finland), a clinical isolate of Candida albicans TU 96942 (University of Turku, Turku, Finland) and C. albicans ATCC 10231 and Saccharomyces cerevisiae ATCC 9763 were used in the bioactivity tests. The strains were stored under liquid nitrogen or at $-80^{\circ} \mathrm{C}$. 


\section{Culture conditions and extraction procedures for HPLC}

Eight suppressive and four non-suppressive isolates were grown at $28^{\circ} \mathrm{C}$ for $96 \mathrm{~h}$ in $10 \mathrm{ml}$ test tubes containing $2 \mathrm{ml} \mathrm{YMG} \mathrm{medium} \mathrm{(yeast} \mathrm{extract:malt}$ extract:glucose, $1 \%$ each, $\mathrm{pH} 7.4$ ) for the assessment of the production of heptaene polyene. Yeast extract was obtained from Difco Laboratories (MI, USA), malt extract from Laihian Mallas (Laihia, Finland) and glucose from Merck (Darmstadt, Germany). The medium was inoculated with $100 \mu \mathrm{l}$ of primary culture ( $2 \mathrm{ml}$ of YMG in $10 \mathrm{ml}$ test tubes inoculated with spores scraped from the agar slants shaken at $28^{\circ} \mathrm{C}$ for $48 \mathrm{~h}$ ). The cultured cell mass was centrifuged ( $5,000 \mathrm{rpm}$ for $5 \mathrm{~min}$ ) and the wet cell mass was weighed and homogenized in $1 \mathrm{ml}$ of $0.05 \mathrm{M}$ ammonium acetate $(\mathrm{pH} 3.8)$-acetonitrile (40:60). The cell mass was centrifuged in $2.0 \mathrm{ml}$ Eppendorf tubes for $15 \mathrm{~min}$ at $15,000 \mathrm{rpm}$. The supernatant containing polyenes was filtered and kept at $-20^{\circ} \mathrm{C}$ until assayed by HPLC. Acetonitrile was HPLC grade (Rathburn, Walkerburn, UK) and ammonium acetate (Merck) was analytical grade. Water in all experiments and analysis was purified using the Milli Q system (Millipore, Molsheim, France).

In addition, antibiotic production of the isolates was tested on YMG agar. The plates were rinsed with $5 \mathrm{ml}$ of sterile water containing Streptomyces spores and incubated at $28^{\circ} \mathrm{C}$ until sporulation was achieved (typically 2 days). An area of agar of about $5 \mathrm{~cm}^{2}$ (4 $\mathrm{mm}$ in depth) was cut out, homogenized with $4 \mathrm{ml}$ of acetonitrile:water (60:40) and centrifuged at $15,000 \mathrm{rpm}$ for $15 \mathrm{~min}$. The extracts were stored at $-20^{\circ} \mathrm{C}$ until assayed by HPLC.

Radioactive antibiotic was prepared by growing the suppressive isolate in the presence of $8-24 \mathrm{kBq}$ of $\left[{ }^{14} \mathrm{C}\right] \mathrm{p}$-aminobenzoic acid $\left(\left[{ }^{14} \mathrm{C}\right] \mathrm{PABA}\right.$, Amersham, UK) in $2 \mathrm{ml}$ of $\mathrm{YMG}$ at $28^{\circ} \mathrm{C}$ for $65 \mathrm{~h}$. The antibiotic was extracted as described above and the radioactive heptaene was analyzed by HPLC using radioactive flow detection.

The cell mass for the isolation, purification and characterization of the heptaene complex was produced by a commercial cultivation process at Kemira Research Centre (Espoo, Finland).

\section{Assay of the heptaene complex by HPLC}

The heptaene concentration from cell mass or agar extracts was determined by HPLC (RAATIKAINEN 1991) using candicidin (Dumex Ltd, Copenhagen, Denmark, $1366 \mathrm{IU} / \mathrm{mg}$ ) as a reference standard. The potency of candicidin standard is designated in international units (IU) which defines the relative amount of antibiotic present in the sample (The United States Pharmacopeial Convention 1989). Briefly, a $20 \mu \mathrm{l}$ aliquot of the acetonitrile extract was injected into a column in a Hewlett Packard 1090 liquid chromatograph (Hewlett Packard, Waldbronn, Germany). The heptaene components were separated on an ODS Hypersil $\mathrm{C}_{18}$ column, $125 \times 4 \mathrm{~mm}$, containing $5 \mu \mathrm{m}$ particles (Bischoff Chromatography, Leonberg, Germany) using isocratic or gradient elution, and the eluate was monitored at $380 \mathrm{~nm}$. $\left[{ }^{14} \mathrm{C}\right]$ radioactivity was counted with radioactivity flow detector as described below. Isocratic elution was performed using $0.05 \mathrm{M}$ ammonium acetate buffer ( $\mathrm{pH}$ 3.8)acetonitrile solution $(62: 38)$ as the mobile phase. Gradient elution was performed according to the method described previously (RAATIKAINEN 1991). Briefly, 0.005 M EDTA (analytical grade, Merck) containing $20 \%$ of methanol-acetonitrile (70:30) was used as the solution $\mathrm{A}$ and acetonitrile as the solution B in the gradient formation. Methanol was HPLC grade (Rathburn). The heptaene components were separated on a column $(125 \mathrm{~mm} \times 4 \mathrm{~mm}$, ID) filled with ODS Hypersil phase (particle size $5 \mu \mathrm{m})$.

Quantitative analysis was performed with gradient elution (RAATIKAINEN 1991), and the sum of the integrated areas of the individual heptaene components was used for quantification. The amount of heptaene was calculated from the total area of heptaene peaks in the sample and from the area of dimethylsulphoxide solution of reference standards.

The $\left[{ }^{14} \mathrm{C}\right]$-labelled heptaene components were monitored by a radioactivity flow detector (Radiomatic FlowOne $\beta / C R$, Radiomatic Instruments and Chemical Co., Tampa, FL, USA) using a $2.5 \mathrm{ml}$ homogeneous flow cell (RAATIKAINEN et al. 1991a). The HPLC effluent was mixed with the scintillant (Flow Scint III, Radiomatic Instruments 
and Chemical Co.) in the ratio $1: 4$, respectively. The counting efficiency was about $68 \%$ and the counts between 5 and $100 \mathrm{keV}$ were accepted for integration.

\section{Classification of heptaenes}

The UV spectrum of polyenes was measured in acetonitrile:water $(60: 40)$ by a double beam spectrophotometer (Jasco, Tokyo, Japan). The presence of sugar and aromatic moieties was analyzed by methods described previously (RAATIKAINEN et al. 1991a). Briefly, mycosamine was identified as its acetylated derivative from the acid hydrolysate of heptaene by GC-MS using amphotericin B (Dumex, Copenhagen, Denmark) as a reference standard. The presence of aromatic groups was determined by GC-MS and HPLC-MS in the alkaline hydrolysate of the heptaene. The hydrolysate was extracted with analytical grade trichloromethane (Merck) and the fraction containing p-aminoacetophenone was purified by semipreparative HPLC, and the purified fraction was analyzed by HPLC and GC-MS. Commercial paminoacetophenone ( $98 \%$, Aldrich-Chemie, Steinheim, Germany) was used as a reference standard.

\section{Isolation of heptaenes}

The harvested cell mass was shaken in water $(\mathrm{pH}$ 3.8)-acetonitrile (40:60) and the residual cell mass was harvested by centrifugation or filtration. $\mathrm{NaCl}$ (analytical grade, Merck) solution (160 g/l) was added to the filtrate and the mixture was shaken until the acetonitrile layer separated. The organic layer was concentrated to about $10 \%$ of the original volume and water was added until precipitate formed. The mixture was kept overnight at $-20^{\circ} \mathrm{C}$ and centrifuged. The centrifugate was washed 3 times with water and finally freeze-dried at $-70^{\circ} \mathrm{C}$ and $10^{-5}$ bar. Additional precipitation was obtained by adding more water to the supernatant of the previous precipitation and by cooling overnight. The antifungal activity of the precipitate was analyzed as described below.

\section{Assay of antifungal activity by bioautography}

The antifungal components of the extracts containing antifungal activity (as tested with agar diffusion, see below) were separated by thin layer chromatography (TLC), and bioautograms were obtained as follows. The TLC plates (Silika K 60, 20 x $20 \mathrm{~mm}$, Merck, Darmstadt, Germany) were developed by trichloromethane: methanol:borate buffer ( $45 \%$ vol of $0.05 \mathrm{M} \mathrm{Na}_{2} \mathrm{~B}_{4} \mathrm{O}_{7}$ (all components were analytical grade, Merck) and $55 \%$ vol of $0.2 \mathrm{M}$ boric acid, $\mathrm{pH} 8.3)$ (7:5:1), dried and overlaid (0.5$1 \mathrm{~mm}$ ) with $1 \%$ potato-dextrose-agar (PDA, Difco Laboratories) containing conidia of either $A$. brassicicola or F. culmorum. The plate was incubated at $28^{\circ} \mathrm{C}$ until inhibition of fungal growth was observed, then the $\mathrm{Rf}$ value for this activity was calculated.

\section{Determination of antifungal activity}

The antifungal activities of the isolated heptaene complexes were determined by their MIC or by agar diffusion assay. A broth dilution test for determining MIC was performed by serially diluting the antibiotic in a buffered peptone-glucose solution (Sabouraud-Glucose-2\%-Bouillon, Merck) according to the method described by SHADOMY et al. (1985). The medium was inoculated with the organism to a final concentration of $10^{5}$ fungal conidia or yeast cells per $\mathrm{ml}$. The tubes were incubated at $28^{\circ} \mathrm{C}$ for $24 \mathrm{~h}$ and the antibiotic concentration of the first clear tube was considered as the MIC value. $F$. culmorum, A. brassicicola, C. albicans TU96942, C. albicans ATCC 10231 and $S$. cerevisiae ATCC 9763 were used as test organisms.

Plate assay for the antifungal activity of various polyene solutions and extracts was performed on plates (diameter $9 \mathrm{~cm}$ ) containing $20 \mathrm{ml}$ of $1 \%$ PDA. The plates were rinsed with 3 to $5 \mathrm{ml}$ of the solution containing the test organism at $10^{5}$ cells $/ \mathrm{ml}$. The solution $(80 \mu \mathrm{l})$ to be tested was pipetted in a well (diameter $8 \mathrm{~mm}$ ) made in the agar with a corkbore, and the plate was incubated at $28^{\circ} \mathrm{C}$, yeast for 24 hours and fungi for 48 hours, when an inhibition zone was formed. The diameter of the 
inhibition zone was taken as a measure of antifungal activity, where the diameter of the well (8 mm) was considered to represent no activity. $C$. albicans TU96942 was used as the test organism.

\section{Results}

\section{Selection of isolates}

The effect of Streptomyces suspension on the severity of disease caused by A. brassicicola was estimated (Table 1). The isolates with a disease index $<0.50$ were classified as suppressive and those with an index $>1.00$ as non-suppressive. The isolates with an index of 0.5-1.0 $(n=3)$ were not selected for further study. The efficiency rate of the isolates was analogous to the disease index, being $>80 \%$ in suppressive strains (Table 1).

\section{Isolation of heptaenes}

Several precipitates containing heptaene components were isolated and freeze-dried, and their purities were tested by comparing their MIC values with their heptaene content (measured by HPLC).

One inhibitory region, typically at $\mathrm{Rf} 0.2$, was found in the bioautography of the extracts. HPLC analysis of the acetonitrile extract of the inhibitory region indicated the presence of heptaene a complex, which was probably decomposed during the TLC assay (chromatograms not shown).

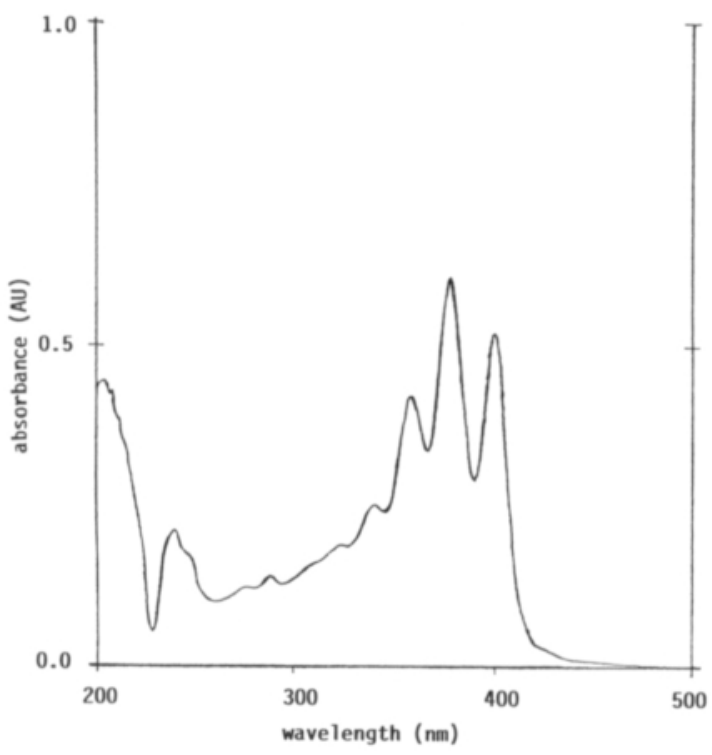

Fig. 1. UV spectrum of the heptaene complex produced by the suppressive Streptomyces griseoviridis isolate 61.

\section{Chemical characterization of heptaenes}

The UV spectrum of the antibiotic was typical of heptaene polyenes, showing characteristic absorption maxima at approximately 360,380 and $400 \mathrm{~nm}$ (Fig. 1). The HPLC chromatogram of the heptaene components produced in the suppressive isolates is of the candicidin type (Fig. 2), and supports the previous suggestion of similarity (RAATIKAINEN 1991). The heptaene complex contained mycosamine similar to that of amphotericin B as shown by GC-MS and LC-MS (data not shown).

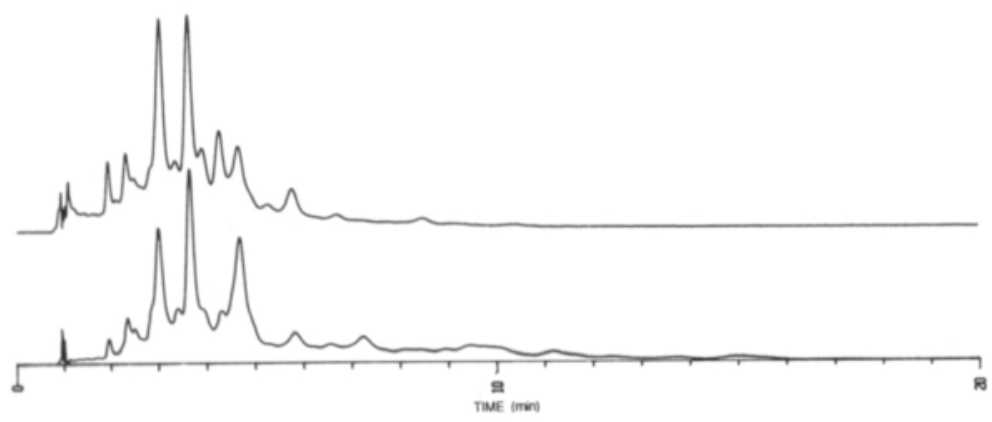

Fig. 2. HPLC separation of the heptaene components produced by Streptomyces griseoviridis (lower) and reference heptaene components of candicidin (upper). The eluate was monitored by a photo diode array detector at $380 \mathrm{~nm}$. The absorbance of the highest peak of candicidin is 0.02 . 

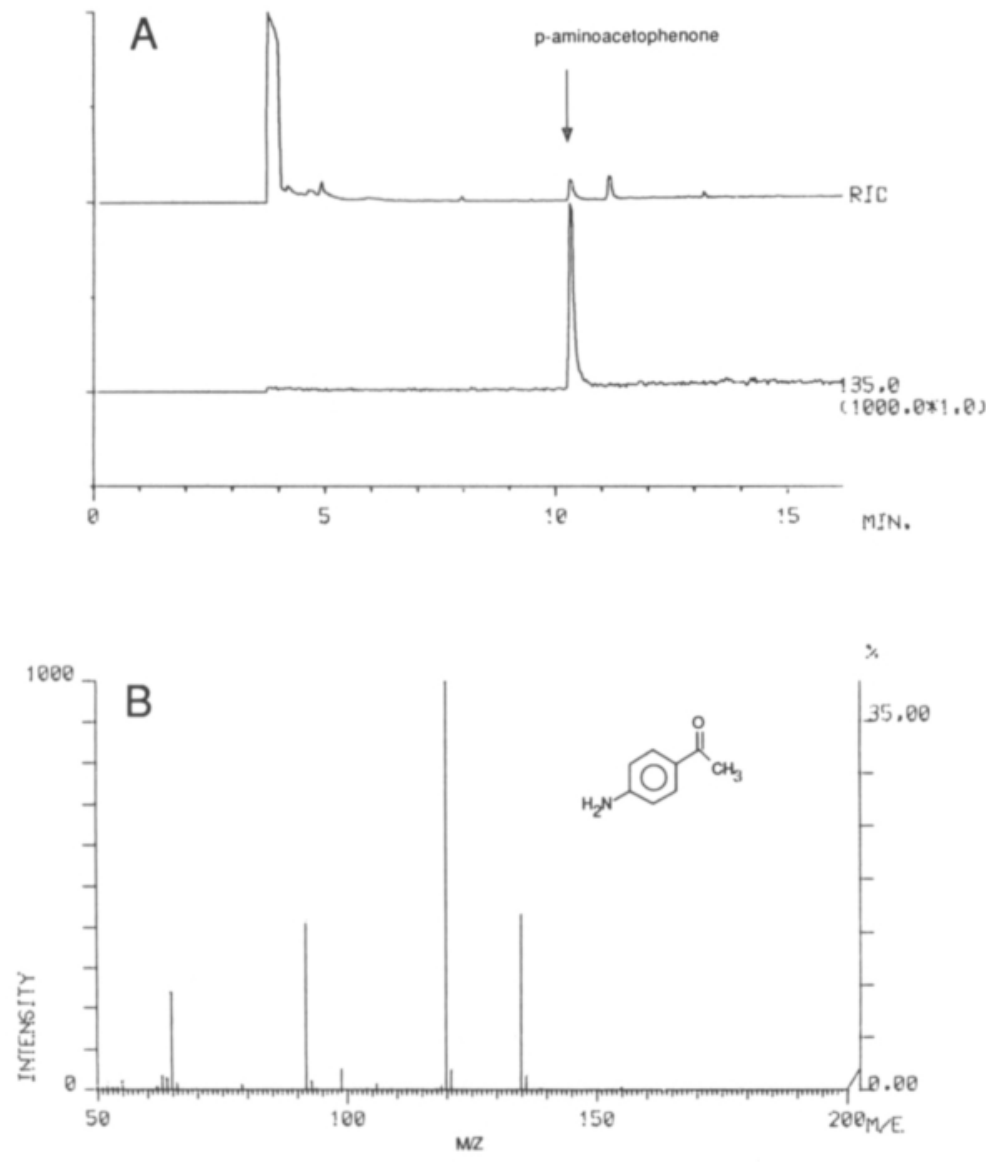

Fig. 3. GC-MS identification of paminoacetophenone released by alkaline hydrolysis from heptaenes produced by Streptomyces griseoviridis. Total ion chromatogram of the HPLC-purified hydrolysate (A) and the fragmentation spectrum of p-aminoacetophenone peak (B).

The GC-MS of the alkaline hydrolysate of the heptaene complex displayed a fragmentation pattern (the three main fragments being M/Z 92, 120 and 135) for p-aminoacetophenone (RAATIKAINEN et. al 1991a), indicating that the heptaene is aromatic (Fig. 3). The latter peak in the total ion chromatogram (Fig. 3a) is probably due to the chlorination of the aromatic ring of p-aminoacetophenone during the extraction process after alkaline hydrolysis. This was supported by the mass spectrum with main $\mathrm{m} / \mathrm{z}$ values of 169 (molecular peak), 154 (base peak) and 126 (spectrum not shown). Formation of p-amino-monochloroacetophenone is most apparent as estimated from the mass spectrum. All individual components demonstrated aromaticity, as indicated by radiochromatography (data not shown), similarly to ${ }^{14} \mathrm{C}$-candicidin (RAATIKAINEN et al. 1991a).

\section{Heptaene production by isolates}

The suppressive Streptomyces isolates were heptaene producers when grown in liquid and on agar culture, and the heptaene containing mycelium extract obtained from liquid culture inhibited the growth of $C$. albicans (Fig. 4). The suppressive isolate 116 produced only minute amounts of the antibiotic in both liquid and agar culture (Fig. 5). Three of the four non-suppressive isolates produced marginal amounts of polyene, and the remaining one (isolate 728) produced only trace amounts (Figs. 4 and 5).

There was a significant difference $(\mathrm{p}<0.01$, Mann Whitney $U$ ) in the polyene productivity in liquid culture between 8 suppressive ( $324.5 \pm 66.2$ $\mathrm{IU} / \mathrm{ml} / \mathrm{gram}$ of wet cell mass) and 4 non-suppressive $(12.0 \pm 3.8 \mathrm{IU} / \mathrm{ml} / \mathrm{g})$ isolates. The anticandidal 


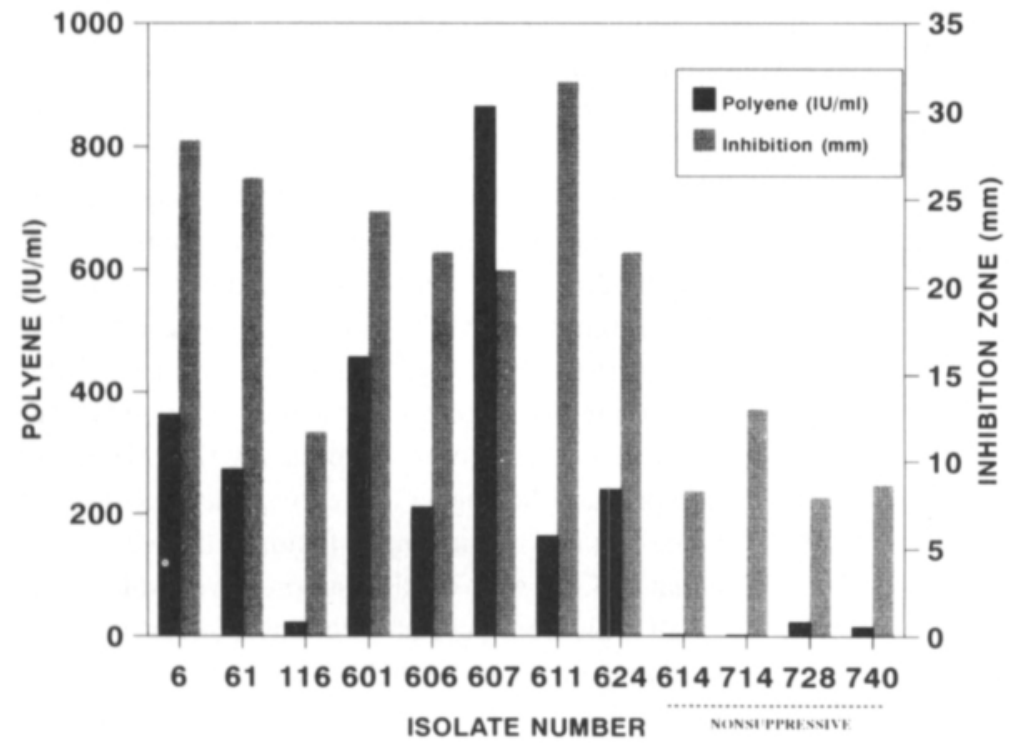

Fig. 4. Production of aromatic heptaenes (black bars) and antifungal activities (grey bars) between suppressive and non-suppressive (dashed line) isolate groups are different $(\mathrm{p}<0.01$, Mann-Whitney U). Production in liquid culture is expressed as the concentration (IU/ ml) of antibiotic in the acetonitrile:water extract from 1 gram of wet mycelium. The antifungal activity of the extracts was tested against the clinical isolate Candida albicans TU 96942 and is shown as the diameter $(\mathrm{mm})$ of the inhibition zone formed in agar diffusion assay.

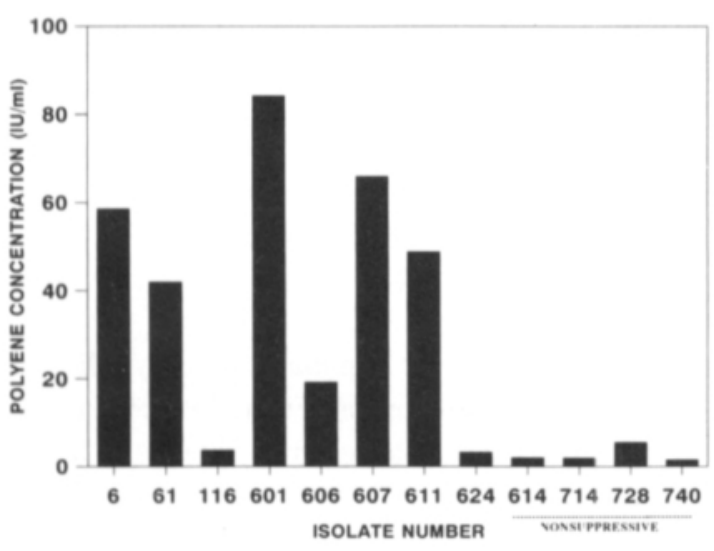

Fig. 5. Production of aromatic heptaenes by suppressive and nonsuppressive (dashed line) isolates on agar plates is significantly different $(\mathrm{p}<0.01$, Mann-Whitney U). Production on agar culture is expressed as the concentration (IU/ml) of antibiotic in the acetonitrile:water extract from agar.

activity of the extracts, as indicated by the growth inhibition zone ( $\mathrm{mm}$ ) of $C$. albicans grown on agar plates, also differed significantly between the suppressive (23.4 \pm 1.4$)$ and nonsuppressive (11.6 \pm $2.5)$ isolates $(p<0.01$, Mann-Whitney $U)$. The growth (as indicated by wet weight of cell mass) of the suppressive isolates $(303.4 \pm 17.0 \mathrm{mg})$ was greater $(\mathrm{p}<0.01$, Mann-Whitney $\mathrm{U}$ ) than that of the nonsuppressive isolates $(198.0 \pm 32.6)$.

The results from agar (Fig. 5) were similar to those obtained from liquid culture, and there was a significant difference $(\mathrm{p}<0.01$, Mann-Whitney $U$ ) between the antibiotic productivity of the suppressive $(40.9 \pm 7.2 \mathrm{IU} / \mathrm{ml}, \mathrm{N}=8$ in duplicate cultures) and non-suppressive ( $2.9 \pm 0.6, \mathrm{~N}=4$ in duplicate cultures) isolates grown on agar.

\section{Antifungal activity of the heptaene complex}

The MIC values of the heptaene complex of this study were the same as those of candicidin and lower than the values for amphotericin B (Table 2). The MIC for the heptaenes was ten times higher against the fungi $(2-4 \mu \mathrm{g} / \mathrm{ml})$ compared to yeasts (0.02-0.3 $\mu \mathrm{g} / \mathrm{ml})$ (Table 2).

\section{Discussion}

The limited usefulness and correlation of culture assays in antibiotic production and biocontrol activity of the test strains have been noted earlier (GoTTlieB 1976, FraVel 1988). The antibiotic ac- 
Table 2. MIC values $(\mu \mathrm{g} / \mathrm{ml})$ of isolated heptaene produced by Streptomyces griseoviridis on the growth of F. culmorum, C. albicans and $S$. cerevisiae.

\begin{tabular}{lccc}
\hline & \multicolumn{3}{c}{ Antibiotic } \\
\cline { 2 - 4 } $\begin{array}{l}\text { Test } \\
\text { organism }\end{array}$ & $\begin{array}{c}\text { Antibiotic } \\
\text { of this study }\end{array}$ & Candicidin & $\begin{array}{c}\text { Amphoteri- } \\
\text { cin B }\end{array}$ \\
\hline $\begin{array}{l}\text { F. culmorum } \\
\text { C. albicans }\end{array}$ & 2 & 2 & 4 \\
$\begin{array}{l}\text { ATCC 10231 } \\
\text { S. cerevisiae } \\
\text { ATCC 9763 }\end{array}$ & 0.03 & 0.03 & $\mathrm{NM}$ \\
\hline
\end{tabular}

$\mathrm{NM}=$ Not measured

Results are from 2-6 measurements per test organism and antibiotic.

tivity, or antagonism, on agar did not correlate with the suppression of plant diseases by test organisms in greenhouse experiments in a study conducted by ROTHROCK and GoTTLIEB (1981). In that study, one strain (Streptomyces noursei) was a polyene (nystatin) producer, but the strain was not effective in controlling plant diseases. The earlier results of SNEH and HENIS (1972) indicated that polyene production was typical of the antagonists used. They could not, however, demonstrate the actual production of polyenes in non-sterile soils or substrates.

The present study suggests that the growth inhibition of the plant pathogens by suppressive Streptomyces isolated from Finnish Sphagnum peat can be partially explained by antibiosis. Cultures of 7 suppressive Streptomyces isolates were producers of a candicidin type heptaene complex. The structures of candicidin D (Fig. 6), one of the main components of the antibiotic complex, and some other aromatic heptaenes have been determined previously (OMURA and TANAKA 1984). Although one isolate (116) was considered to be suppressive, it produced only small amounts of heptaene both in liquid and in agar culture. In addition to isolate 116, some contradiction could be seen between the antifungal activity and polyene production of certain suppressive isolates (Fig. 4), but the reason could not be clarified in this study. This contradiction may be due to differences in the genetic control of the antibiotic biosynthesis causing variation in the antibiotic productivity. Another exception was the nonsuppressive isolate 714 which exhibited some anticandidal activity in the bioassay (Fig. 4). It did not produce heptaene, indicating the presence of some unknown antifungal factor. The reason for enhanced growth of the suppressive isolates in small scale liquid culture remains unclear. Perhaps they are simply more viable than the non-suppressive isolates in this medium, since their growth on agar was also better.

Suppressive isolates typically produced similar patterns of individual heptaene components as indicated by HPLC (data not shown). The aromatic group in all individual components was p-aminoacetophenone and the sugar moiety was mycosamine, reflecting the similarity with candicidin (Fig. 6). Thus the identification of the aromatic group by HPLC-MS provides a technique to determine the total amount of aromatic heptaenes present in soil samples.

Our results did not eliminate the possibility of non-suppressive isolates producing heptaene in the presence of other carbon sources. When a rich medium, containing yeast extract, malt extract and glucose was used as the growth medium, no significant production of polyene was found. The nutritional environment, however, may affect the antibiosis and biocontrol as suggested by FRAVEL (1988). Studies on the nature of the bald mutant of one of the suppressive $S$. griseoviridis (isolate 61) indicated that the carbon source of minimal me-

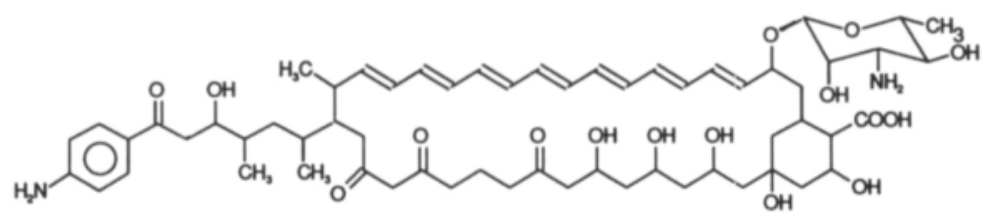

Fig. 6. The structure of candicidin $\mathrm{D}$, showing the aromatic (left) and sugar moieties (right) attached to the macrolide ring (OMURA and TANAKA 1984). 
dium (HOPWOOD et al. 1985) affected the heptaene production (HOLMALAHTI et al. 1993).

It is known that the heptaene polyene antibiotics bind to the ergosterol molecules in the fungal or animal cell membrane, and together they form ion conducting pores that make the plasma membrane leaky to monovalent and divalent cations (BOLARD 1986, RAATIKAINEN et al. 1991b). This apparently stimulates fungal cell respiration, increasing the energy demand, ultimately resulting in cell death.

In addition to antibiosis by heptaenes, the other known mechanisms of antagonism (eg. hyperparasitism, production of siderophores, competition) are also likely, and it has been suggested that one of the suppressive isolates produced extracellular enzymes with lytic characteristics (TAPIO and POHTOLAHDENPERÄ 1991). The production of chitinase was supported by the growth of $S$. griseoviridis isolate 61 on chitin (unpublished results), though further research on the activities of extracellular enzymes is needed to firmly establish this mechanism.
The production of polyene antibiotics can be used as a marker in screening of the biocontrol activity among isolates of Streptomyces. Although a significant correlation between suppressiveness and polyene productivity exists, only limited conclusions may be drawn on the role of antibiosis in this antagonism by these results. Studies with nonproducing mutants, originating from suppressive strains, could clarify the mechanism of their antagonistic action. On the other hand determinations of the heptaene components in greenhouse substrates are a promising way to assess the role of antibiosis.

Acknowledgements. This study was financially supported by Kemira Research Centre (Espoo, Finland), Kemira Foundation (Helsinki, Finland) and the Provincial Government of Kuopio (Kuopio, Finland). We thank Mr. P. Seiskari M.Sc. (Eng.) for the fermentations and Dr. S. Auriola Ph.D. (Pharm.) for performing the MS analysis. The skilful technical assistance of Mrs Arja Kinnunen and Mr. Jukka Knuutinen is acknowledged.

\section{References}

Bolard, J. 1986. How do the polyene macrolide antibiotics affect the cellular membrane properties? Biochim. Biophys. Acta 864: 257-304.

FrAVEL, D.R. 1988. Role of antibiosis in the biocontrol of plant diseases. Ann. Rev. Phytopathol. 26: 75-91.

GoTtLIEB, D. 1976. The production and role of antibiotics in soil. J. Antibiot. 29: 987-1000.

Holmalahti, J., RaAtikainen, O. \& Wright, A. von 1993. Transformable mutants of a biopesticide strain Streptomyces griseoviridis K61. J. Ind. Microbiol. 11: 193-198.

Hopwood, D.A., BibB, M.J., Chater, K.F., KIESER, T., Bruton, C.J., Kieser, H.M., Lydiate, D.J., Smith, C.P., WARD, J.M. \& SCHREMPF, H. 1985. Genetic Manipulation of Streptomyces. A Laboratory Manual, The John Innes Foundation, Norwich, U.K.

LAHDENPERÃ, M.-L. 1991. Streptomyces - A new tool for controlling plant diseases. Agro-Industry $\mathrm{Hi}-\mathrm{Tech} 2$ : 25-27.

—, Simon, E. \& Uotı, J. 1991. Mycostop - a novel biofungicide based on Streptomyces bacteria. In: Beemster, A.B.R. et al. (eds.). Biotic interactions and soil-borne diseases. Proceedings of the first conference of the Europian Foundation for Plant Pathology. Elsevier, Amsterdam. p. 258-263.

Martin, J.F. \& McDaniel, L. E. 1977. Production of polyene macrolide antibiotics. Adv. Appl. Microbiol. 21: 1-52.

Omura, S. \& TanaKa, H. 1984. Production, structure, and antifungal activity of polyene macrolides. In: Omura S. (ed.). Macrolide Antibiotics, Chemistry, Biology, and Practice, Academic Press, Inc. p. 351-404.

RaAtikainen, O. 1991. Assay of heptaene polyenes by HPLC. Characterization of heptaene produced by Streptomyces griseoviridis. J. Chromatogr. 588: 355-359.

-, Auriola, S. \& Tuomisto, J. 1991a. Identification of aromatic moieties and mycosamine of antifungal heptaenes with highperformance liquid chromatography, high-performance liquid chromatographymass spectrometry, and gas chromatography-mass spectrometry. J. Chromatogr. 585: 247-254.

-, Kauppinen, R. A., Komulainen, H., Taipale, H., Pirttilä, T. \& Tuomisto, J. 1991b. Polyene antibiotics increase the ionic permeability of synaptosomal plasma membranes. Biochem. Pharmacol. 41: 1345-1350.

Rothrock, C.S. \& GotTlieB, D. 1981. Importance of antibiotic production in antagonism of selected Streptomyces species to two soil-bome plant pathogens. J. Antibiot. 34: 830-835.

— \& GotTlieB, D. 1984. Role of antibiosis in antagonism of Streptomyces hygroscopicus var. geldanus to Rhizoctonia solani in soil. Can. J. Microbiol. 30: 1440-1447. 
Shadomy, S., Espinel-Ingroff, A. \& CARTwright, R.Y. 1985. Laboratory studies with antifungal agents: susceptibility tests and bioassays. In: Lennette, E.H. et al. (eds.). Manual of clinical microbiology, fourth edition. American Society for Microbiology, Washington, D.C. p. 991.

SNEH, B. \& HenIS, Y. 1972. Production of antifungal substances active against Rhizoctonia solani in chitinamended soil. Phytopathology 62: 595-600.

TAHVONEn, R. 1982a. The suppressiveness of Finnish light coloured Sphagnum peat. J. Sci. Agric. Soc. Finl. 54: $1-12$.

- 1982b. Preliminary experiments into the use of Streptomyces spp. isolated from peat in the biological control of soil and seed-borne diseases in peat culture. J. Sci. Agric. Soc. Finl. 54: 13-25.

— \& Avikainen, H. 1987. The biological control of seedborne Alternaria brassicicola of cruciferous plants with a powdery preparation of Streptomyces sp. J. Sci. Agric. Soc. Finl. 59: 199-207.

TAHVONEN, R. T. 1988. Microbial control of plant diseases with Streptomyces spp.. Bull. OEPP/EPPO Bull. 18: 5559.

TAPIO, E. \& Pohto-LAhDENPERÄ, A. 1991. Scanning electron microscopy of hyphal interaction between Streptomyces griseoviridis and some plant pathogenic fungi. J. Sci. Agric. Soc. Finl. 63: 435-441.

The United States Pharmacopeial Convention 1989. Biological tests and assays. Antibiotics - microbial assays. In: USP XXII. The United States Pharmacopeia. p. 14881493. The United States Pharmacopeial Convention, Inc., Rocville, MD.
WELLER, D.M. 1988. Biological control of soilborne plant pathogens in the rhizosphere with bacteria. Annual Review of Phytopathology 26: 379-407.

Williams, S.T. 1986. The ecology of antibiotic production. Microbial Ecology 12: 43-52.

\section{Manuscript received April 1993}

Olavi Raatikainen

University of Kuopio

Department of Pharmaceutical Chemistry

P.O. Box 1627

FIN-70211 Kuopio, Finland

Jouko Tuomisto

National Public Health Institute

Division of Environmental Health

P.O. Box 95

FIN-70701 Kuopio, Finland

\section{Risto Tahvonen}

Agricultural Research Centre of Finland

Institute of Plant Protection

FIN-31600 Jokioinen, Finland

Heikki Rosenqvist

Helsinki University of Technology

Department of Biochemistry and Microbiology

FIN-02150 Espoo, Finland

\title{
SELOSTUS
}

\section{Rahkaturpeesta eristettyjen Streptomyces-bakteerien biologinen torjuntateho ja antibioottituotto}

\author{
OlAVi RAATIKAINEN, Jouko TUOMISTO, RISTO TAHVONEN ja \\ HEIKKI ROSENQVIST
}

Kuopion yliopisto, Kansanterveyslaitos, Maatalouden tutkimuskeskus ja Teknillinen Korkeakoulu

Rahkaturpeesta eristetyt biologisen torjuntatehon omaavat Streptomyces-bakteerit muodostivat laboratorio-olosuhteissa kasvatettaessa polyeeniantibiootteja. Torjuntateho testattiin kasvihuonekokein, joissa käytettiin testiorganismina Alternaria brassicicola -hometta.

Antibiootit muodostavat rakenteeltaan samankaltaisten yhdisteiden seoksen, jonka komponentit voidaan erotella nestekromatografisesti. Antibiootit ovat heptaeenipolyeenejä, joille on tyypillistä 7 konjugoitua kaksoissidosta. Kaksoissi- dosrakenne arvioitiin heptaeeneille tyypillisen ultraviolettispektrin avulla. Lisäksi antibiooteissa on aromaattinen ja sokeriosa, jotka tunnistettiin massaspektrometrisesti.

Heptaeenien tuottokykyä voidaan käyttää hyvăksi biofungisidien kehitystyössä. Heptaeenien tai niistä irrotettujen aromaattisten tai sokeriosien analysointia voidaan soveltaa arvioitaessa antibioosin merkitystä biofungisidien vaikutusmekanismissa. 